\title{
LEADERSHIP - THE KEY ELEMENT IN IMPROVING QUALITY MANAGEMENT
}

\author{
IVETA PAULOVÁ, MIROSLAVA MĹKVA
}

\section{INTRODUCTION}

The current approach to a quality management system is based on principles that were specified on the basis of experience and good practices and approaches of major leaders in the field of quality management. Eight principles were defined that nowadays create the backbone of the implementation of a quality management system and are incorporated in the standards of ISO 9000:2005. The first principle is leadership.

Leadership is a developmental process, which is based on the type of choice a leader makes (Mostovicz, Kakabadse \& Kakabadse, 2009).

Leadership leads managers to a fundamental approach that in turn lead to action, an example for others, understanding and flexible reactions to changes in their environment, the constant consideration of the needs of all concerned, including: customers, owners, suppliers, local communities and society as a whole. Their main task is to state the clear visions of an organisation's future, setting values and an ethical constellation of roles at all levels of an organization, to provide the staff with necessary resources and freedom of decision making for activities under their responsibility, to develop an open and decent communication, setting challenging goals and aspirations, using strategies to reach these aims.

Consequently, leaders need to recognise that the choices they make for organisational activities have to fit their own worldview. Pursuing the fit between one's worldview and planned organisational activities ensures that leaders continuously improve their ethical behaviour (Mostovicz, Kakabadse \& Kakabadse, 2009).

Leadership depends not only on the official status of a leader, but it is important and essential that leaders are sufficiently competent in the planning, communication and management and also they have be able to develop vision of the organization, how to implement them as well as made to ensure the participation of workers in their implementation. Management should be engaged in the processes with a model attitude and should be able to engage the whole organization actively in achieving objectives (Paulová, 2009).

Practical experience shows the important role of leaders in improving quality management and the organization itself. 
Leaders of an organization establish unity of purpose and direction of it. They should go for creation and maintenance of such an internal environment, in which people can become fully involved in achieving the organization's quality objective (Cianfrani \& West, 2009).

One of the tasks of the survey was to determine the level of perception of leaders and leadership in the organization and their impact on quality management improvement, including all related tasks.

We have also based on claims (Zgodavová, 2002) that the basic finding when examining the key factors in the development of small and medium-sized Slovak organizations is the leadership of organisations. Therefore we give a survey of Slovak industrial companies.

\section{METHODOLOGY}

Within the solving of the research project "Perspectives of quality management development in coherence with requirements of the Slovak Republic' market," we dealt with the issues of quality management applications in various branches of industrial practice. Through the survey, we assessed the level of application of the fundamental principles on which are quality management systems are designed.

The survey we conducted, via a questionnaire, was attended by 124 organizations in Slovakia from enterprises of different sizes. During evaluating the data, we divided the organizations into four groups according to company size and then we surveyed whether they had introduced or certified the quality management system. The structure of surveyed enterprises according to size of the enterprises was as follows: $4 \%$ of micro enterprises, $19 \%$ small enterprises, $30 \%$ middle enterprises, and 47\% large enterprises. Almost all surveyed enterprises had implemented and certified a quality management system, so when evaluating the data we did not use this criterion for the distribution of enterprises.

Survey questions were formulated based on the requirements of normative documents for quality management systems with a focus on using eight basic principles of quality management. Based on questionnaires from which we obtained interesting results, we can conclude that in the set of surveyed organizations, the application of the basic principles of total quality management was at quite a good level. Regarding the evaluation of individual policies, not all areas with each principle are implemented in business practice sufficiently or on the desired level (Kučerová, Vaňová, 2011). In this paper we will focus on issues with which we were investigating how are in practice implemented activities related with the principle of leadership.

First we tried to figure out how that principle is understood and applied in business practice, in quality management and whether there are differences in its application in business practice, in organizations of various sizes. In this paper 
we present some results obtained from a survey of the issues to which the questionnaire was designed from the following questions:

1. How is the principle of leadership understood in your organization?

2. Has an investigation taken place regarding the organisation's mission, vision and values with respect to changes of the external environment?

3. In your organization are the executives generally seen not just as authority but also as a pattern of attitudes and procedures?

4. What is the involvement of top management to management of processes, including improvement?

When asked "How is the principle of leadership understood in your organization?" we have the following options for response (Figure 1):

a) key principle for quality management system

b) the key principle for a functioning quality management system

c) managers are an ideal model of behaviour for all employees

d) important for the competitiveness of the organization

e) important for the strategic direction

f) significant for providing the right resources for individual processes.

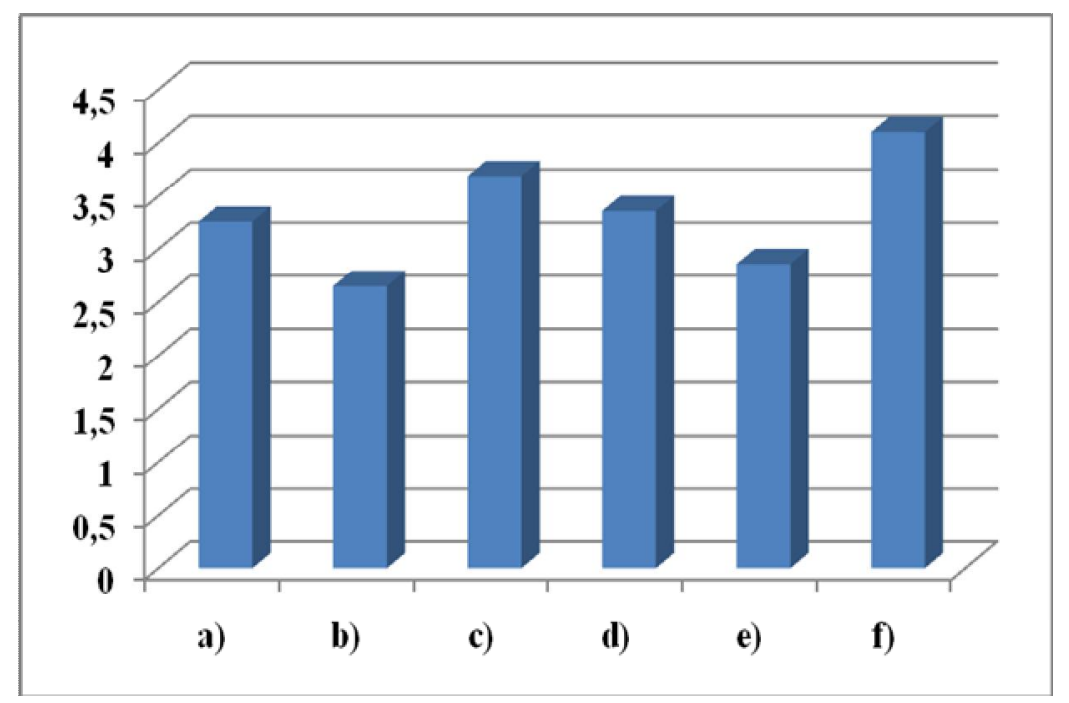

Figure 1 - Graphical representation of responses to question no. 1

When answering a given question, the respondents ranged individual possibilities according to the importance they attach to them. In evaluating this issue, we expressed the values in the table using the weighted average.

The results of the responses show that the principle of leadership in organizations, regardless of certification, is especially seen as a key principle for a functioning quality management system. When considering all the 
organizations, the second place in order of importance includes the option e) important for the strategic direction. The least important, respondents identified the option f) significant administrative resources to provide for individual processes.

Another issue we tried to determine whether the organization reviewed its mission, vision and values with respect to changes in the external environment (requirements of concerned sides, legislation, region, banks, foreign markets). Respondents had the following options (Figure 2):
a) regularly
b) on the announced or emerging changes
c) randomly
d) not examined
e) other
f) did not respond

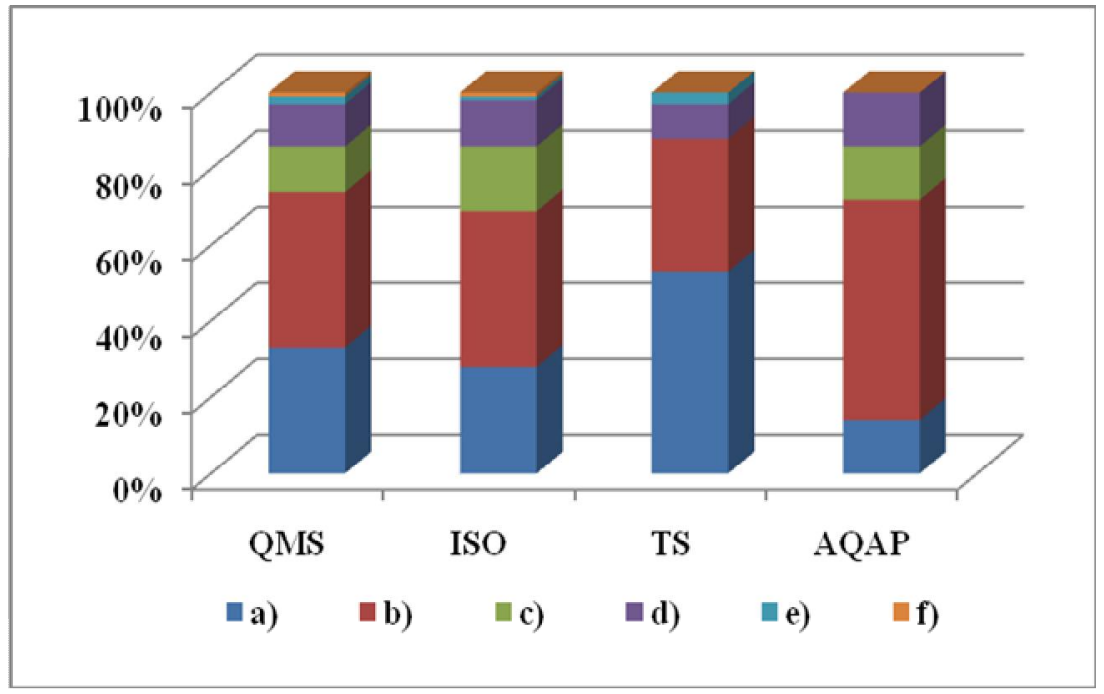

Figure 2 - Graphical representation of responses to question no. 2

As part of strategic management it is important to set out the future direction of the organization, articulate mission, vision and values to be followed in responding to them. From the answers to the question of the review mission, vision and values with regard to changes in environment, we can conclude that $33 \%$ of organizations do regularly review, $41 \%$ at the announced changes, $12 \%$ random and $11 \%$ does not do review.

When dividing a file according to an established quality management system, we found differences in the implementation of the review mission, vision and values with regard to changes of environment. The organisations with a TS 16949 certificate make regular reviews in $53 \%$, with ISO 9001 in $28 \%$ and with AQAP 
only in $14 \%$. It can be concluded that in organizations with the implementation of QMS according to TS 16949 standards dealing with a review mission, vision and values give greater attention than in the organizations with other type of QMS.

With the following question, we investigated whether in the organization the executives are in general seen not just as authority but also the ideal in the attitudes and actions. Possible answers were (Figure 3):
a) yes
b) mostly yes
c) mostly not
d) no
e) I cannot judge
f) did not respond

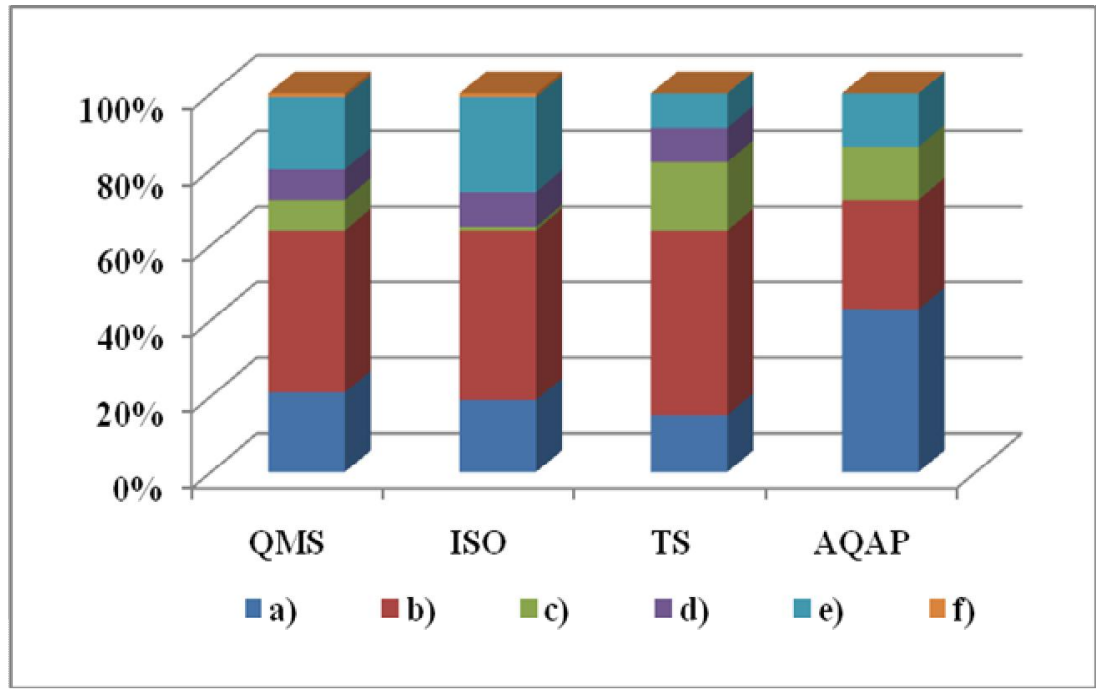

Figure 3 - Graphic representation of responses to question no. 3

The mission of manager is primarily to ensure the fulfilment of the objectives of the organization and to develop human potential in the organization. In fulfilling this mission it is important to be worthy for others to follow as an example and to motivate staff. When asked about the perception of managers in organizations in Slovakia with the established QMS system, we found that $64 \%$ of organizations are managers that are largely perceived as authoritative and a pattern in attitudes and behaviour, which is important in terms of meeting the principles of leadership.

In organizations with the system according to AQAP standards was this perception manifested as the most obvious. $43 \%$ of respondents have chosen the 
unambiguous "yes" for perception of manager as an authority and pattern in attitudes. No respondent has chosen unambiguous "no" (i.e. the answer d).

As one of the key tasks of leaders is making more effective the management of activities (processes) in the organization, the next question was investigating the involvement of leaders in this field (the issue). Possible answers were (Figure 4):

a) the active participation of management in the selected processes

b) the active participation only in management processes

c) active participation in the processes of generating profit of organizations (implementation processes)

d) in cases of urgency

e) is not involved

f) other

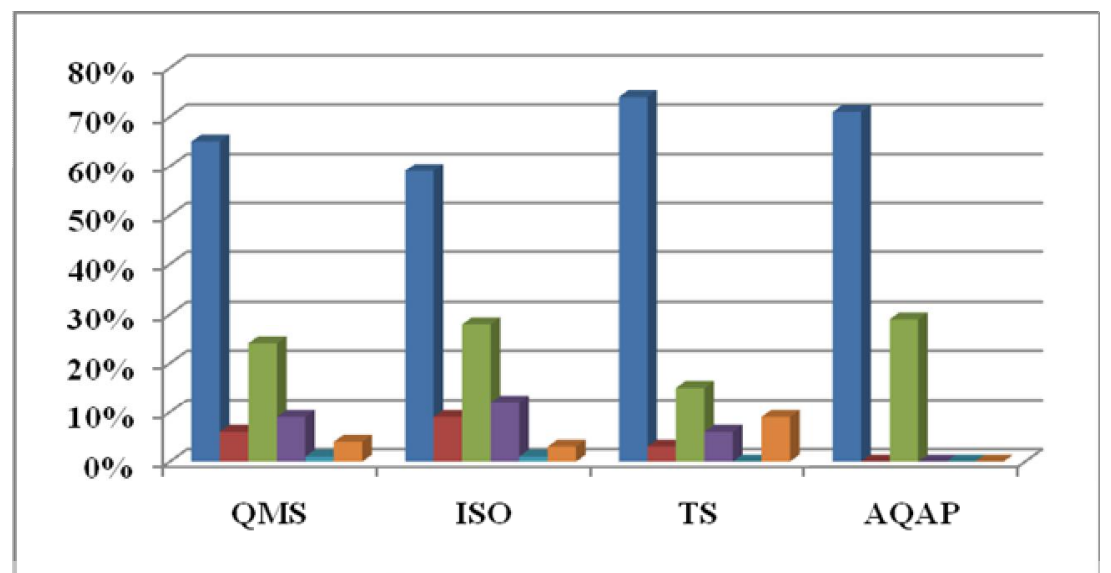

Figure 4 - Graphic representation of responses to question no. 4

The respondents had the possibility to designate more answers at this question.

Percentage assessment of the individual responses is expressed with regard to the total number of organizations (117 organizations with QMS) and the number of organizations certified under each model (69 organizations with ISO, 34 organizations with TS, 14 organizations with AQAP).

The question of the involvement of top management to process management was answered by significantly the largest number of organizations, as illustrated also on the above chart, by answer a) an active participation of management in the selected processes. Furthermore, we can state that the top management is directly involved in improving such processes that are involved in making profit of organizations. These are probably also the processes that are owned by top managers. Least of all was the possibility of responses represented by e) is not involved. In response, "other" the respondents in most cases, stated the 
involvement of management to all processes. There were no significant differences in responses while dividing the file according the QMS certificate.

\section{CONCLUSION}

Questionnaire survey, by which we tried to find out the level of applied principles of quality management in industrial practice within Slovakia. We obtained interesting results. We did not find striking differences between individual sectors, although in some areas their appeared smaller or larger differences in the applied principles of quality management. These differences, however, mostly result from the specific conditions of the particular industry.

The best level of applying the principles of quality management was in the automotive industry, which logically follows from the stricter requirements, as stated in the technical specification of TS 16949. Managers in organizations must deal with the new role of leader as an example of behaviour in attitudes and values. As the survey has shown, the principle of leadership in all types of organizations is mainly seen as a key principle for a functioning quality management system. Of those surveyed organisations that answered "yes" $21 \%$ and "mostly yes" $43 \%$ of organizations answered that managers are perceived as authoritative and an example in attitudes and behaviour. The largest number of answers "yes", which means a clear perception of managers as an example were in organisations with certificate according to standards AQAP ("yes" $43 \%$ "mostly yes" 29\%), for at least with certificate TS 16949 ("yes" 15\% "mostly yes" $49 \%)$.

Organizations with an established quality management system tend to review the mission, vision and values of the announced changes, respectively emerging changes. In terms of dynamic development and turbulent changes within the current globalized world, such an approach is insufficient. Strategic management is directed into the future and focuses on a long-term perspective. From this perspective, it is necessary to regularly review compliance and deal with set goals and aspirations with the requirements of the environment. Currently, the organization and management could not wait for change, but they have to encourage and incite them if they want to compete. Experience of successful enterprises points to the need to be a step forward.

If properly fulfilling the principles of leadership, it is necessary to focus primarily on the following areas (Paulová et al., 2010):

- ensure the proper direction the organization, to pay the attention to strategic management, regularly reviewing the mission, vision and values,

- to develop the processes in the organization and organizational structure in accordance with the established strategy, needs and expectations of stakeholders, to react flexibly to changes in the external environment (market, competition, legislation, etc.), 
- not to respond immediately to changes, but to prepare for them specifically,

- define appropriate managerial forms (management levels, functions, responsibilities, competencies),

- develop leadership skills and qualities of managers (identification of key competencies to be developed),

- strengthen mutual trust between managers (leaders) and staff, to ensure the opportunity to provide feedback on personal assessment, evaluation interviews, discussions,

- create conditions for effective communication, maintain regular staff awareness of key issues concerning the organization,

- create an environment encouraging the creativity, culture of innovation and improvement, by encouraging and supporting staff to design innovation and improvement, be proactive in their daily activities,

- strictly follow the principles of business ethics and generally accepted values, to integrate the ethical principles already into the strategic plans,

- ensure a positive perception of the organization by immediate environment by the, applying the of CSR principles,

- build a corporate culture with clearly defined objectives, which is an integrating element, connects people and helps to achieve the organizational objectives and flexibly react to changes.

The personal involvement of managers (leaders) is a prerequisite for achieving the above ideas. Fulfilment can be achieved by increasing the skills of managers, their management and leadership skills as well as the knowledge in strategic management, use of corporate culture in managing, motivating employees to fulfil the objectives of the organization. The behaviour of the organization leaders helps to create clarity and unity of the aim and an environment in which the organization and its employees operate. Everyday example of managers / leaders behaviour in accordance with the objectives and values is for employees more motivating, more encouraging and worthy to follow than the declared policy. The leaders must create a customer orientation, clear and visible quality values, and high expectations. This concept stresses the personal involvement required of leaders. This involvement extends to areas of public responsibility and corporate citizenship as well as to areas of development of the entire work force (Juran, 1998).

Organizations should create their own analysis of training needs of managers (and other staff) and develop a training system that would respond to specific requirements and needs of the organization and reflects its strategic direction. 


\section{REFERENCES}

Cianfrani, Ch. A. \& West, J. E. (2009), Cracking the Case of ISO 9001:2008 for Service: A Simple Guide to Implementing Quality Management to Service Organizations ( $2^{\text {nd }}$ ed.), Milwaukee: American Society for Quality, pp. 5-7. ISBN 978-0-87389-762-4.

ISO 9001:2008, Quality Management Systems - Requirements.

ISO TS 16949 Quality management systems - Particular requirements for the application of ISO 9001:2000 for automotive production and relevant service part organizations

Juran J. M., Blanton Godfrey A. (1998), Juran's Quality Handbook, Fifth edition, McGraw-Hill Companies, Singapore, ISBN 0-07-116539-8

Kučerová, M., Vaňová, J. (2011), Perspektívy rozvoja manažérstva kvality v priemyselných podnikoch na Slovensku. In: Nové trendy v manažérstve kvality [CD ROM] : 4. ročník medzinárodného vedeckého seminára, 12 - 13 apríl 2011, Trnava. Trnava: AlumniPress, 2011. ISBN 978-80-8096-143-5, p. 148-153

Mostovicz, E. I., Kakabadse, N. K., Kakabadse, A. P. (2009), A dynamic theory of leadership development, Leadership \& Organization Development Journal, Vol. 30 Iss: 6, pp. $563-576$

Paulová, I. (2009), Chosen Methods of System Approach in Quality Management and TQM Efficiency and Effectivity Evaluation. - $1^{\text {st }}$ ed. - Köthen : Hochschule Anhalt, 2009, 96 p., (Scientific monographs), ISBN 978-3-86011-024-9

Paulová, I., a kolektív (2010), Perspektívy rozvoja manažérstva kvality $v$ súvislosti s požiadavkami trhu Slovenskej republiky, AlumniPress, Trnava, 2010, ISBN 987-80-8096-129-9

Paulová, I.; Kučerova, M. \& Míkva, M. (2009), The Application of Process Approach in Quality Management in Terms of Slovak Republic, Annals of DAAAM for 2009 \& Proceedings of the 20th International DAAAM Symposium, 25-28th November 2009, Vienna, Austria, ISSN 1726-9679, ISBN 978-3901509-70-4, Katalinic, B. (Ed.), pp. 0893-0894, Published by DAAAM International Vienna, Vienna

Zgodavová, K. (2002), Factors of Intensive Product and Service Quality Improvement, Journal of Economics, Volume 50/No. 6/2002, ISSN 0013-3035 


\section{ABOUT THE AUTHOR \\ Assoc. prof. Iveta Paulová, PhD. - associate professor at the Faculty of Materials Science and Technology in Trnava, Slovak University of Technology in Bratislava, Slovakia, e-mail: iveta.paulova@stuba.sk \\ Miroslava Míkva, PhD. - senior lecturer at the Faculty of Materials Science and Technology in Trnava, Slovak University of Technology in Bratislava, Slovakia, e-mail: miroslava.mlkva@stuba.sk}

